\title{
IMPORTANCE PERFORMANCE ANALYSIS JEMAAH HAJI KEMENTERIAN AGAMA KOTA BANJARMASIN
}

\author{
Mardhiatin Nisa Rohama \\ Pramubakti Tenaga Kependidikan Kopertais Wilayah XI Kalimantan, Banjarmasin, \\ Indonesia \\ Email: mardhiatin@gmail.com
}

Restu Khaliq

Fakultas Dakwah dan IImu Komunikasi, UIN Antasari, Banjarmasin, Indonesia Email: restu.khaliq@gmail.com

\begin{abstract}
Professional public services are needed by the public as customers of public services, including the Hajj service. This study intends to measure the level of satisfaction of pilgrims to the quality of Hajj services in the Ministry of Religion of Banjarmasin City in 1438 H / 2017 M using the Importance Performance Analysis (IPA) method. The respondents of this study were go people. The results of this study indicated that the dimensions of responsiveness and assurance are the top priority for improvement. In addition there was a place of complaint for items scattered/missing goods congregation, employees/officers master the ins and outs of hajj and current issues in Saudi Arabia, fast and appropriate services in providing information on departure/calling congregation, giving health care to sick congregations, as well as facilities the complete practice of Hajj rituals were services attribute that must be improved in quality.
\end{abstract}

KEYWORDS Importance; Performance; Hajj

\section{Pendahuluan}

Ibadah haji merupakan suatu ritual ibadah yang termasuk dalam rukun Islam yang kelima setelah syahadat, shalat, puasa, dan zakat. Ibadah haji dilakukan sebagai kegiatan ibadah tahunan yang dilakukan oleh umat muslim yang ada di seluruh dunia. Ibadah ini dilakukan oleh muslim yang mampu dan memenuhi syarat. Ibadah ini terangkum dalam rangkaian kegiatan pada periode tertentu yang disebut musim haji di beberapa tempat di Arab Saudi. Umat muslim yang mampu (istitha'ah) di seluruh belahan dunia mempunyai kewajiban yang sama dalam pelaksanaan ibadah ini. Indonesia merupakan negara kepulauan yang mayoritasnya penduduknya muslim dengan persentasi secara kuantitas mempunyai jumlah terbesar di dunia. Jumlah yang besar ini sebanding dengan minat terhadap melaksanakan haji. 
Animo masyarakat untuk menunaikan ibadah haji dari tahun ke tahun cenderung meningkat, ditandai semakin bervariasinya profil jemaah haji dalam beberapa tahun terakhir ini. Latar belakang jemaah haji selama ini sebagian besar (lebih dari 6o\%), berasal dari daerah pedesaan dengan tingkat pendapatan rendah, mulai menurun sedangkan dari kalangan masyarakat kota seperti; tokohtokoh penting, pegawai negeri maupun swasta, militer, pengusaha dan intelektual, mulai meningkat dalam menunaikan ibadah haji. Perhitungan statistik mengambarkan peningkatan jumlah jemaah haji yang berasal dari perkotaan dengan tingkat pendidikan tinggi (Nidjam \& Hanan, 2001).

Pelayanan publik yang professional dibutuhkan oleh masyarakat sebagai pelanggan dari pelayanan publik, karena masyarakat memiliki kebutuhan dan harapan pada kinerja penyelenggara. Pemerintah mempunyai tanggung jawab dan kewenangan dalam menentukan standar pelayanan minimal. Sayangnya pelayanan publik oleh pemerintah seringkali menjadi sorotan. Berbagai keluhan masyarakat yang disampaikan melalui media massa adalah salah satu indikatornya. Hal ini bisa menciptakan citra negatif untuk aparatur pemerintah. Sebagai pelayan masyarakat, pemerintah perlu terus berusaha meningkatkan kualitas pelayanan (Zaenal Mukarom \& Muhibudin Wijaya Laksana, 2015).

Importance Performance Analysis (IPA) adalah metode yang berkaitan erat dengan kepuasaan pelanggan. Keunggulan metode ini terletak pada kemudahan interpretasi hasil dan biayanya yang rendah.(Khaliq, 2018a) Pengukuran kepuasan pelanggan sering didiskuksikan dalam literatur pemasaran adalah service quality dengan model SERVQUAL (Khaliq, 2018b). Dimensi yang sering digunakan adalah dimensi kehandalan (reliability), daya tanggap (responsiveness), empati (empathy), bukti fisik (tangible), dan jaminan (assurance). Pengukuran ini banyak digunakan dalam mengukur tingkat kepuasan pelanggan terutama dalam bidang jasa. Tingkat kepuasan pelayanan jamaah hajipun bisa diukur menggunakan SERVQUAL menggunakan metode Importance Performance Analysis (IPA).

Kemenag kota Banjarmasin merupakan salah satu penyelenggara pemerintah dengan jumlah pendaftar serta keberangkatan terbanyak dibandingkan dengan kementerian kota/kabupaten lain di Kalimantan Selatan, yakni sebanyak 757 jemaah, hal ini menjadi sebuah tantangan bagi Kemenag Kota Banjarmasin, apakah jemaah sudah merasakan kesesuaian antara harapan dengan kebutuhan pelayan yang diberikan oleh pihak penyelenggara selama proses dari mulai pendaftaran, pembinaan hingga keberangkatan serta kepulangan.

Uraian di atas memunculkan gagasan penelitian tentang tingkat kepuasan jemaah haji terhadap kualitas pelayanan haji di Kementerian Agama Kota Banjarmasin tahun $1438 \mathrm{H} / 2017 \mathrm{M}$ menggunakan metode Importance Performance Analysis (IPA). 


\section{Kajian Teori}

A. Ibadah Haji

Haji adalah salah satu rukun Islam kelima yang diwajibkan Allah SWT kepada orang-orang yang mampu menunaikannya. Ibadah ini bagi seorang muslim diwajibkan untuk dilaksanakan sekali seumur hidup, kewajiban ini baru disyariatkan pada tahun ke-6 Hijriyah (Taufiqurrahman, 2009). Dalam ibadah haji dilakukan rangkaian kegiatan seperti thawaf dan sai di Baitullah, wukuf di padang Arafah, melempar jumrah dan pelaksanaan ibadah haji lainya yang dijalankan sesuai dengan petunjuk Rasulullah.(Mangkuto, 2008) Tanggung jawab pelaksanaan ibadah haji berada pada Menteri Agama. Direktorat Jenderal Penyelenggaraan Haji dan Umrah (Ditjen PHU) adalah instansi yang bertanggung jawab secara struktural dan teknis fungsional (Sensuse \& Maulana, 2011).

\section{B. Pelayanan}

Ivancevich, Lorensi, Skinner, dan Crosby mendefinisikan "pelayanan" sebagai produk yang tidak kasat mata, tidak dapat diraba dimana usaha-usaha manusia dan peralatan terlibat di dalamnya (Ivancevich, Lorensi, Skinner, \& Crosby, 2000). Sementara itu Gronroos menjelaskan bahwa pelayanan adalah aktivitas atau serangkainan aktivitas yang sifatnya tidak kasat mata, tidak bisa diraba, terjadi karena interaksi yang terjadi antara konsumen dengan karyawan atau hal-hal lain dari pemberi pelayanan untuk memecahkan permasalahan pelanggannya (Gronroos, 2000).

Adapun pelayanan umum dapat diartikan sebagai segala bentuk jasa pelayanan yang pada prinsipnya menjadi tanggung jawab dan dilaksanakan oleh instansi pemerintah dalam upaya pemenuhan kebutuhan masyarakat (Zaenal Mukarom \& Muhibudin Wijaya Laksana, 2015). Beberapa ciri-ciri pelayanan yang baik diantaranya adalah memiliki sumber daya manusia yang profesional, sarana dan prasarana yang baik, serta waktu pelayanan yang cepat dan tepat.(Kashmir, 2005) Dalam pelayanan publik seperti pelayanan ibadah haji pelayanan yang baik harus diperhatikan oleh pihak pemerintah terutama oleh Direktorat Jenderal Penyelenggaraan Haji dan Umrah (Ditjen PHU) selaku penanggung jawab secara struktural dan teknis fungsional.

\section{Service Quality}

Salah satu pendekatan kualitas pelayanan yang banyak dijadikan acuan dalam riset pemasaran adalah metode SERVOUAL (Service Quality) yang dapat didefinisikan sebagai seberapa jauh perbedaan antara kenyataan dan harapan pelanggan yang diterima pelanggan (Lupiyoadi \& Rambat, 2006). Dimensi SERVOUAL untuk mengevaluasi kualitas pelayanan yaitu: 1) Kehandalan (reliability) yaitu kemampuan memberi layanan dengan segera sesuai janji yang diberikan. 2) Jaminan (assurance) yaitu kepercayaan pelanggan terkaiat kemampuan para staf serta bebas dari berbagai risiko dan keragu-raguan. 3) Daya 
tanggap (responsiveness) yaitu ketanggapan staf pelayanan untuk membantu pelanggan. 4) Empati (empathy) terkait pemahaman kebutuhan pelanggan dan kemudahan komunikasi yang dilakukan oleh para staf pelayan. 5) Bukti fisik (tangible) mulai fasilitas, perlengkapan, staf dan sarana komunikasi (Yuriansyah, 2013).

Pemerintah akan memberikan pelayanan untuk jamaah haji dalam bentuk pelayanan umum, administrasi, ibadah dan kesehatan. Pelayanan umum yang diberikan adalah pelayanan asrama jemaah haji serta transportasi. Pelayanan ibadah adalah pelayanan pemerintah mulai dari bimbingan manasik haji serta hal-hal yang berkaitan dengan ibadah seperti tayammum dan shalat di pesawat, shalat jama' dan qashar. Pelayanan administrasi adalah pelayanan yang diberikan mulai dari pendaftaran, paspor, panggilan masuk asrama. Sementara itu, pelayanan kesehatan meliputi pemeriksaan kesehatan biaya pemeriksaan kesehatan dan penyerahan kartu kesehatan (Nahrawi \& Syaukani, 2009).

\section{Kepuasan Pelanggan}

Kepuasan pelanggan adalah dampak dari perbandingan antara harapan pelanggan sebelum dilayani dengan realita pelayanan yang diterima pelanggan (Sumarwan, 2003). Dampak ini adalah keputusan pelanggan berdasarkan pengalamannya terhadap jasa yang diperoleh dengan membandingkan ekspektasi pelanggan (Wijaya, 2011). Secara sederhana terdapat dua faktor utama dalam kepuasan pelanggan yaitu jasa yang diharapkan (expected service) dan jasa yang dipersepsikan (perceived service) (Parasuraman, Zeithaml, \& Berry, 1985). Kepuasan pelanggan ini adalah wujud evaluasi pelanggan setelah pelanggan merasakan pelayanan yang diberikan yang setidaknya memenuhi atau melebihi harapan pelanggan (Sunyoto, 2012).

\section{E. Importance Performance Analysis}

Importance Performance Analysis adalah metode yang diidentifikasi sebagai quadrant analysis diperkenalkan oleh Martilla dan James untuk menilai tingkat kepentingan dan kinerja (Martilla \& James, 1977). Dalam metode ini, penilaian dilakukan dengan membagi 4 kuadran penilaian dimana masing-masing kuadran memiliki makna yang berbeda. Gamble dan Gambel menjabarkan makna masing-masing kuadran; (Gamble \& Gambel, 2002) 1) Kuadran A - Prioritas Utama (Concentrate Here) untuk kategori faktor yang sangat penting bagi pemberi pelayanan untuk memperhatikan dan mengalokasikan sumber daya yang lebih pada faktor-faktoryang terdapat dalam kuadran ini. 2) Kuadran B - Pertahankan Kinerja (Keep Up The Good Work) untuk faktor penunjang dimana pemberi pelayanan dapat dikatakan berhasil memaksimalkan faktor-faktor yang ada sehingga dituntut agar bisa mempertahannya. 3) Kuadran C - Prioritas Rendah (Low Priority) untuk faktor-faktor dengan prioritas yang rendah. 4) Kuadran D Berlebihan (Possible Overkill) untuk faktor-faktor yang tidak terlalu penting dan 
pihak pemberi pelayanan dapat merubah arah prioritasnya kepada faktor-faktor lain yang lebih penting. Berikut adalah gambar kuadran model Importance Performance Analysis (IPA).

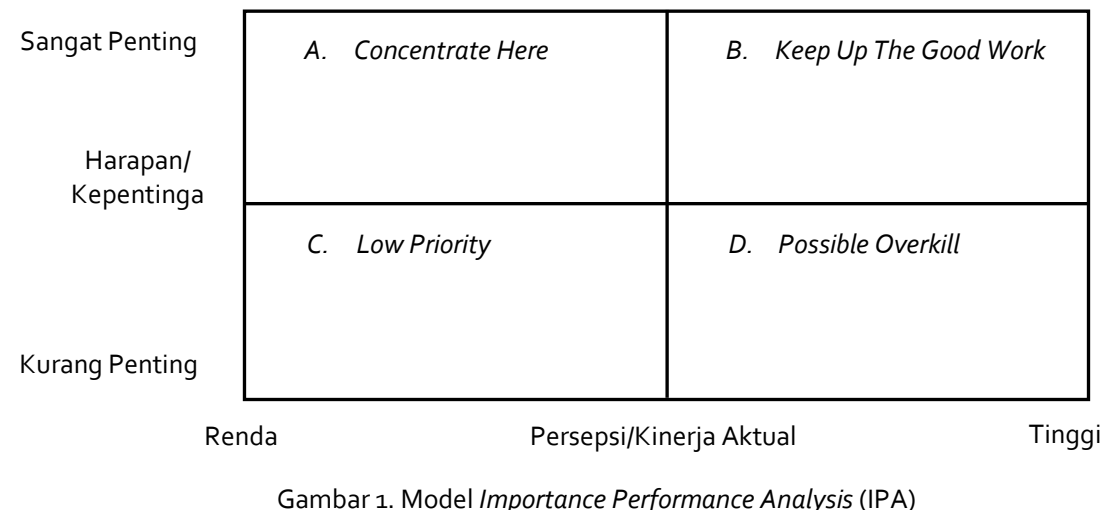

\section{Metode}

A. Tujuan dan Responden Penelitian

Tujuan penelitian ini adalah untuk mengidentifikasi kepuasan jamaah haji akan pelayanan pemerintah Kemenag Kota Banjarmasin dalam proses ibadah haji menggunakan metode Importance Performance Analysis. Responden penelitian ini diambil dari jamaah haji Kota Banjarmasin yang berangkat haji pada tahun 1438 $\mathrm{H} / 2017 \mathrm{M}$.

B. Variabel dan Instrumen Penelitian.

Variabel penelitian ini berdasar pada variabel service quality dengan dimensi kehandalan (reliability), jaminan (assurance), daya tanggap (responsiveness), empati (empathy) serta bukti fisik (tangible). Pengukuran variabel service quality tersebut akan mewakili dua kategori, yaitu kategori tingkat harapan (importance) dan tingkat kinerja (performance). Variabel yang mewakili tingkat harapan (importance) diukur dengan skala pengukuran yaitu $1=$ sangat tidak penting, 2 = tidak terlalu penting, 3 = biasa saja, $4=$ penting $5=$ sangat penting . Sementara variabel yang mewakili tingkat kinerja (performance) diukur dengan skala pengukuran yaitu 1 = sangat tidak setuju, 2 = tidak terlalu setuju, 3 = biasa saja, 4 = setuju 5 = sangat setuju. Instrumen penelitian ini berupa kuesioner yang berisi pernyataan tentang service quality dengan lima dimensinya. Berikut adalah indikator pernyataan yang terbagi dalam lima dimensi service quality penelitian ini: 
Tabel 1. Indikator Pertanyaan

\begin{tabular}{|c|c|c|}
\hline $\begin{array}{l}\text { Dimensi } \\
\text { Pelayanan }\end{array}$ & $\begin{array}{c}\text { Item } \\
\text { Pernyataan }\end{array}$ & Indikator Pertanyaan \\
\hline \multirow[t]{7}{*}{$\begin{array}{l}\text { Kehandalan } \\
\text { (Reliable) }\end{array}$} & 1 & $\begin{array}{l}\text { Pelayanan yang cepat dan tepat dalam memberikan } \\
\text { informasi keberangkatan/ pemanggilan jemaah }\end{array}$ \\
\hline & 3 & $\begin{array}{l}\text { Adanya penjadwalan yang baik dan rutin kegiatan } \\
\text { manasik haji di daerah }\end{array}$ \\
\hline & 4 & $\begin{array}{l}\text { Kejelasan penyampaian materi dan jawaban terhadap } \\
\text { pertanyaan saat manasik haji }\end{array}$ \\
\hline & 7 & Makanan yang sesuai selera jemaah di asrama haji \\
\hline & 9 & Jemaah diberikan bimbingan/ penyuluhan pasca haji \\
\hline & 10 & Ketepatan waktu bekerja pegawai/petugas haji (disiplin) \\
\hline & 16 & $\begin{array}{l}\text { Adanya pelayan yang baik dalam pemeriksaan } \\
\text { kesehatan jemaah sebelum pemberangkatan (di daerah) }\end{array}$ \\
\hline \multirow[t]{4}{*}{$\begin{array}{l}\text { Keyakinan } \\
\text { (Assurance) }\end{array}$} & 6 & $\begin{array}{l}\text { Pemberian kepastian informasi jadwal keberangkatan } \\
\text { calon jemaah }\end{array}$ \\
\hline & 11 & $\begin{array}{l}\text { Pegawai/petugas menguasai seluk beluk haji dan isu } \\
\text { mutakhir keadaan di Arab Saudi }\end{array}$ \\
\hline & 14 & Petugas/pegawai berpakaian rapi \\
\hline & 18 & $\begin{array}{l}\text { Tersedia adanya tempat pengaduan untuk barang } \\
\text { tercecer/hilang barang jemaah }\end{array}$ \\
\hline \multirow{4}{*}{$\begin{array}{c}\text { Daya } \\
\text { Tanggap } \\
\text { (Responsiven } \\
\text { ess) }\end{array}$} & 5 & $\begin{array}{l}\text { Kesigapan petugas dalam menjawab dan menyelesaikan } \\
\text { permasalahan yang dialami jemaah }\end{array}$ \\
\hline & 8 & $\begin{array}{l}\text { Kesigapan petugas dalam mengarahkan jemaah yang } \\
\text { ingin berangkat atau datang dari tanah suci }\end{array}$ \\
\hline & 17 & Pemberian pelayanan kesehatan bagi jemaah sakit \\
\hline & 19 & $\begin{array}{l}\text { Ketersediaan dan keterbukaan Kemenag Kota } \\
\text { Banjarmasin dalam menerima setiap keluhan }\end{array}$ \\
\hline \multirow[t]{4}{*}{$\begin{array}{c}\text { Empati } \\
\text { (Emphaty) }\end{array}$} & 2 & $\begin{array}{l}\text { Kemudahan calon jemaah dalam mengurus dokumen- } \\
\text { dokumen pendaftaran dan pemberkasan persyaratan } \\
\text { haji }\end{array}$ \\
\hline & 12 & Petugas/pegawai yang ramah dan murah senyum \\
\hline & 13 & Petugas/pegawai yang bersahabat \\
\hline & 15 & $\begin{array}{l}\text { Petugas memberi perhatian tanpa membedakan strata } \\
\text { jemaah }\end{array}$ \\
\hline \multirow{6}{*}{$\begin{array}{l}\text { Bukti Fisik } \\
\text { (Tangiable) }\end{array}$} & 20 & Halaman kantor Kemenag Kota Banjarmasin yang luas \\
\hline & 21 & Sarana praktek manasik haji yang lengkap \\
\hline & 22 & $\begin{array}{l}\text { Adanya sarana, prasarana, fasilitas pendaftaran haji } \\
\text { yang memadai }\end{array}$ \\
\hline & 23 & $\begin{array}{l}\text { Adanya perlengkapan atribut jemaah yang baik (buku } \\
\text { bimbingan, koper, tas jinjing/dokumen, seragam, gelang } \\
\text { identitas) }\end{array}$ \\
\hline & 24 & Tempat tidur yang nyaman saat di asrama haji \\
\hline & 25 & Kamar mandi yang nyaman di asrama haji \\
\hline
\end{tabular}




\begin{tabular}{|c|c|c|}
\hline $\begin{array}{l}\text { Dimensi } \\
\text { Pelayanan }\end{array}$ & $\begin{array}{c}\text { Item } \\
\text { Pernyataan }\end{array}$ & Indikator Pertanyaan \\
\hline & 26 & $\begin{array}{l}\text { Kebersihan, kerapian dan penataan ruang/fasilitas di } \\
\text { Kemenag Kota Banjarmasin }\end{array}$ \\
\hline & 27 & $\begin{array}{l}\text { Transportasi yang mengantarkan jemaah dari asrama ke } \\
\text { embarkasi dan sebaliknya }\end{array}$ \\
\hline
\end{tabular}

\section{Populasi, Prosedur Pengumpulan dan Analisis Data}

Pada penelitian isi yang menjadi responden adalah jemaah haji Kota Banjarmasin yang berangkat di tahun 1439 H/ 2017 M yakni sebanyak 90 responden dari 757 jemaah. Kuesioner dibagikan kepada responden yang sudah melaksankan haji dan mengikuti rangkaian kegiatan yang diprogram oleh Kementerian Agama Kota Banjarmasin Tahun 2017. Data yang terkumpul dari kuesioner akan dilakukan analisis validitas, reliabilitas dan analisis Importance Performance Analysis.

\section{Hasil Penelitian dan Pembahasan}

\section{A. Karekteristik Responden}

Jumlah responden jemaah haji Kota Banjarmasin yang berangkat di tahun $1439 \mathrm{H} / 2017$ M pada penelitian ini terdiri dari 39 orang laki-laki dan 50 orang perempuan, sementara 1 orang lainnya tidak memberikan identitas pribadi dengan alasan kerahasiaan. Berdasarkan kategori umur, jemaah yang paling banyak menjadi responden adalah jemaah haji yang berada pada kategori dewasa akhir yakni usia 36 sampai 55 tahun dan lansia awal yakni usia 46 sampai 55 tahun dengan jumlah yang sama yaitu sebanyak 32 orang $(35,56 \%)$. Selanjutnya adalah jemaah berusia lansia akhir yakni usia 56 sampai 80 tahun sebanyak 22 orang $(24,44 \%)$ hanya sedikit yang berada di usia dewasa awal yaitu sebanyak 3 orang $(3,33 \%)$. Satu orang lainnya tidak memberikan identitas pribadi karena alasan kerahasiaan. Pendidikan jemaah haji sebagian besar responden adalah jemaah yang sudah tinggi tingkat pendidikannya, yakni Si sebanyak 34,44\% diikuti oleh SMA/MA 25,56\%.

Tabel 2. Karakteristik Responden

\begin{tabular}{|c|c|c|c|}
\hline & Kategori & Jumlah & Persentase \\
\hline \multirow{3}{*}{ Jenis Kelamin } & Laki-laki & 39 orang & $43,33 \%$ \\
\hline & Perempuan & 50 orang & $55,56 \%$ \\
\hline & $\begin{array}{l}\text { Tidak mengisi } \\
\text { identitas }\end{array}$ & 1 orang & $1,11 \%$ \\
\hline \multicolumn{2}{|c|}{ Jumlah } & 90 orang & $100 \%$ \\
\hline \multirow{2}{*}{$\begin{array}{c}\text { Kategori } \\
\text { Umur }\end{array}$} & $\begin{array}{c}\text { 26-35 (dewasa } \\
\text { awal) }\end{array}$ & 3 orang & $3,33 \%$ \\
\hline & $\begin{array}{c}\text { 36-45 (dewasa } \\
\text { akhir) }\end{array}$ & 32 orang & $35,56 \%$ \\
\hline
\end{tabular}




\begin{tabular}{|c|c|c|c|}
\hline & Kategori & Jumlah & Persentase \\
\hline & 46-55 (lansia awal) & 32 orang & $35,56 \%$ \\
\hline & 56-8o (lansia akhir) & 22 orang & $24,44 \%$ \\
\hline & $\begin{array}{c}\text { Tidak mengisi } \\
\text { identitas }\end{array}$ & 1 orang & $1,11 \%$ \\
\hline & Jumlah & 90 orang & $100 \%$ \\
\hline \multirow{10}{*}{$\begin{array}{l}\text { Pendidikan } \\
\text { Terakhir }\end{array}$} & $\mathrm{SD} / \mathrm{MI}$ & 11 orang & $12,22 \%$ \\
\hline & SMP/MTs & 9 orang & $10 \%$ \\
\hline & SMA/MA & 23 orang & $25,56 \%$ \\
\hline & Pesantren & 1 orang & $1,11 \%$ \\
\hline & Diploma & 2 orang & $2,22 \%$ \\
\hline & $\mathrm{S}_{1}$ & 31 orang & $34,44 \%$ \\
\hline & $\mathrm{S} 2$ & 9 orang & $10 \%$ \\
\hline & $\mathrm{S}_{3}$ & 3 orang & $3,33 \%$ \\
\hline & Tidak mengisi & & $1,11 \%$ \\
\hline & identitas & 1 orang & \\
\hline \multicolumn{2}{|r|}{ Jumlah } & 90 orang & $100 \%$ \\
\hline
\end{tabular}

B. Uji Validitas dan Reliabilitas

Dalam menentukan validitas dengan jumlah responden sebanyak 90 diperlukan nilai $r$ product moment di atas nilai 0,202. Berdasarkan perhitungan statistik, atribut service quality yang untuk mengkonstruksi tingkat harapan (importance) dan tingkat kinerja (performance) menunjukkan hasil yang valid. Hal ini karena seluruh nilai hitung $r$ product moment di atas nilai 0,202. Berikut adalah informasi lengkapnya:

Tabel 3. Validitas Instrumen Penelitian

\begin{tabular}{|c|c|c|c|c|c|}
\hline \multirow[b]{2}{*}{ Dimensi } & \multirow{2}{*}{$\begin{array}{c}\text { Item } \\
\text { Pertanyaan }\end{array}$} & \multicolumn{2}{|c|}{ Importance } & \multicolumn{2}{|c|}{ Performance } \\
\hline & & $\begin{array}{c}r \\
\text { hitung }\end{array}$ & Keterangan & $\begin{array}{c}r \\
\text { hitung }\end{array}$ & Keterangan \\
\hline \multirow{7}{*}{$\begin{array}{l}\text { Kehandalan } \\
\text { (Reliability) }\end{array}$} & $\mathrm{Q}_{1}$ & 0,668 & valid & 0,595 & Valid \\
\hline & $\mathrm{O}_{3}$ & 0,619 & valid & 0,619 & Valid \\
\hline & $\mathrm{O}_{4}$ & 0,616 & valid & 0,654 & Valid \\
\hline & Q7 & 0,642 & valid & 0,720 & Valid \\
\hline & Q9 & 0,633 & valid & 0,719 & Valid \\
\hline & $\mathrm{Q}_{10}$ & 0,642 & valid & 0,615 & Valid \\
\hline & $\mathrm{Q}_{16}$ & 0,540 & valid & 0,568 & Valid \\
\hline \multirow{4}{*}{$\begin{array}{c}\text { Jaminan } \\
\text { (Assurance) }\end{array}$} & Q6 & 0,631 & valid & 0,609 & Valid \\
\hline & Q11 & 0,698 & valid & 0,631 & Valid \\
\hline & Q14 & 0,536 & valid & 0,556 & Valid \\
\hline & Q18 & 0,669 & valid & 0,686 & Valid \\
\hline
\end{tabular}




\begin{tabular}{|c|c|c|c|c|c|}
\hline \multirow[b]{2}{*}{ Dimensi } & \multirow{2}{*}{$\begin{array}{c}\text { Item } \\
\text { Pertanyaan }\end{array}$} & \multicolumn{2}{|c|}{ Importance } & \multicolumn{2}{|c|}{ Performance } \\
\hline & & $\begin{array}{c}\mathrm{r} \\
\text { hitung }\end{array}$ & Keterangan & $\begin{array}{c}\mathrm{r} \\
\text { hitung }\end{array}$ & Keterangan \\
\hline \multirow{4}{*}{$\begin{array}{c}\text { Daya Tanggap } \\
\text { (Responsiveness) }\end{array}$} & $\mathrm{Q}_{5}$ & 0,706 & valid & 0,749 & Valid \\
\hline & Q8 & 0,749 & valid & 0,706 & Valid \\
\hline & Q17 & 0,650 & valid & 0,660 & Valid \\
\hline & Q19 & 0,793 & valid & 0,710 & Valid \\
\hline \multirow{4}{*}{$\begin{array}{c}\text { Empati } \\
\text { (Empathy) }\end{array}$} & $\mathrm{O}_{2}$ & 0,545 & valid & 0,602 & Valid \\
\hline & $\mathrm{Q}_{12}$ & 0,655 & valid & 0,612 & Valid \\
\hline & $\mathrm{Q}_{13}$ & 0,725 & valid & 0,687 & Valid \\
\hline & $\mathrm{Q}_{15}$ & 0,722 & valid & 0,689 & Valid \\
\hline \multirow{8}{*}{$\begin{array}{l}\text { Bukti Fisik } \\
\text { (Tangible) }\end{array}$} & $\mathrm{Q}_{20}$ & 0,726 & valid & 0,732 & Valid \\
\hline & Q21 & 0,627 & valid & 0,596 & Valid \\
\hline & $\mathrm{Q} 22$ & 0,732 & valid & 0,703 & Valid \\
\hline & Q23 & 0,719 & valid & 0,700 & Valid \\
\hline & Q24 & 0,681 & valid & 0,651 & Valid \\
\hline & $\mathrm{Q}_{25}$ & 0,731 & valid & 0,543 & Valid \\
\hline & $\mathrm{O} 26$ & 0,840 & valid & 0,770 & Valid \\
\hline & Q27 & 0,705 & valid & 0,583 & Valid \\
\hline
\end{tabular}

Uji reliabilitas yang mengukur kehandalan disimpulkan reliabel jika memiliki Cronbach's Alpha lebih besar dari o,6o. Variabel penelitian ini dikatakan reliabel karena nilai Cronbach's Alpha lebih besar dari o,6o. Hal tersebut dilihat pada tabel berikut:

Tabel 4. Reliabilitas Instrumen Penelitian

\begin{tabular}{ccccc}
\hline Dimensi Variabel & $\begin{array}{c}\text { Cronbach's Alpha } \\
\text { Kepentingan } \\
\text { (Importance) }\end{array}$ & Keterangan & $\begin{array}{c}\text { Cronbach's Alpha } \\
\text { Kinerja } \\
\text { (Performance) }\end{array}$ & Keterangan \\
\hline Kehandalan (Reliability) & 0,871 & reliabel & 0,879 & reliabel \\
\hline Jaminan (Assurance) & 0,771 & reliabel & 0,726 & reliabel \\
\hline Daya Tanggap (Responsiveness) & 0,876 & reliabel & 0,838 & reliabel \\
\hline Empati (Empathy) & 0,781 & reliabel & 0,812 & reliabel \\
\hline Bukti Fisik (Tangible) & 0,948 & reliabel & 0,920 & reliabel \\
\hline
\end{tabular}

\section{Pemetaan Importance Performance Analysis}

Analisis kepentingan dan kinerja dapat dilakukan dengan cara membandingkan rata-rata masing-masing atribut. Apabila nilai rata-rata kinerja sesuai dengan atau melebihi rata-rata tingkat kepentingan maka jemaah dinilai puas. Sebaliknya apabila nilai rata-rata kinerja lebih kecil dari pada nilai rata-rata tingkat kepentingan maka jemaah dinilai tidak puas. 
Tabel 5. Rata-Rata Kepentingan (Importance) dan Kinerja (Performance)

\begin{tabular}{clcc}
\multicolumn{5}{c}{ Perdimensi } \\
\hline No & \multicolumn{1}{c}{ Dimensi } & $\begin{array}{c}\text { Kepentingan } \\
\text { (Importance) }\end{array}$ & $\begin{array}{c}\text { Kinerja } \\
\text { (Performance) }\end{array}$ \\
\hline 1 & Kehandalan (Reliability) & 4,37 & 4,01 \\
\hline 2 & $\begin{array}{l}\text { Daya } \\
\text { (Responsiveness) }\end{array}$ & 4,47 & 3,94 \\
\hline 3 & Empati (Empathy) & 4,43 & 4,06 \\
\hline 4 & Bukti Fisik (Tangible) & 4,45 & 4,10 \\
\hline 5 & Jaminan (Assurance) & 4,44 & 3,98 \\
\hline
\end{tabular}

Berdasarkan hasil perhitungan mean maka didapatkan untuk variabel kepentingan (importance) nilai tertinggi yaitu daya tanggap (responsiveness) dan nilai terendah adalah kehandalan (reliability). Hasil perhitungan mean maka didapatkan untuk variabel kinerja (performance) nilai tertinggi pada dimensi bukti fisik (tangible) dan nilai terendah pada dimensi daya tanggap (responsiveness). Selanjutnya perbandingan dimensi variabel kinerja (performance) secara berurutan ialah bukti fisik (tangible), kehandalan (reliability), empati (empathy), jaminan (assurance), dan daya tanggap (responsivenes). Dari data di atas maka dapat di buat pemetaan Importance Performance Analysis berdasarkan dimensinya sebagai berikut:

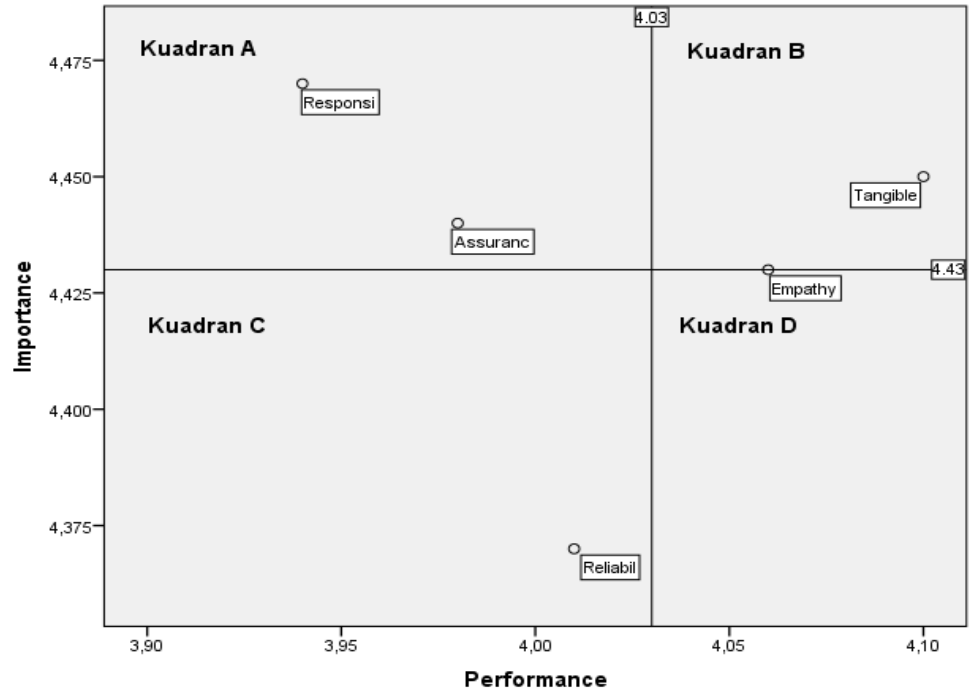

Gambar 2. Pemetaan Importance Performance Analysis Berdasarkan Dimensi Variabel

Dari diagram tersebut dapat diambil kesimpulan bahwa yang perlu perhatian dan menjadi prioritas utama untuk ditingkatkan kinerjanya adalah variabel dimensi yang berada di kuadran A yaitu daya tanggap (responsiveness) 
dan jaminan (assurance), hal ini karena jemaah memiliki persepsi terhadap variabel kepentingan (importance) terhadap dimensi tersebut tinggi, namun kinerja (performance) yang dirasakan oleh jemaah belum sesuai dengan yang diharapkan. Pada kuadran B yaitu bukti fisik (tangible), memiliki tingkat kinerja dan kepentingan yang sudah tinggi, artinya prestasi ini sudah sesuai dan harus tetap di pertahankan. Diantara kuadran B dan D terdapat dimensi empati (emphaty), dalam posisi ini artinya kinerja terhadap dimensi ini sudah baik, jika kemudian kepentingan dari atribut ini akan meningkat dimasa mendatang maka Kemenag Kota Banjarmasin sudah mendapat kelebihan (unggul) karena sudah mempunyai kinerja yang baik. Pada posisi kuadran $C$ terdapat variabel dimensi kehandalan (reliability), posisi ini mengindikasikan bahwa kinerja atas dimensi ini perlu perbaikan tetapi sifatnya tidak mendesak.

Adapun analisis tingkat kepentingan (importance) dan tingkat kinerja (performance) peratribut adalah sebagai berikut:

Tabel 6. Rata-Rata Kepentingan (Importance) dan Kinerja (Performance) Peritem Pertanyaan.

\begin{tabular}{|c|c|c|c|c|}
\hline No & Daftar Pertanyaan & Importance & Performance & Gap \\
\hline 1 & $\begin{array}{l}\text { Pelayanan yang cepat dan tepat } \\
\text { dalam memberikan informasi } \\
\text { keberangkatan/pemanggilan } \\
\text { Jemaah }\end{array}$ & 4,61 & 3,99 & $-0,62$ \\
\hline 2 & $\begin{array}{l}\text { Kemudahan dalam mengurus } \\
\text { dokumen-dokumen pendaftaran } \\
\text { dan pemberkasan calon jemaah } \\
\text { haji }\end{array}$ & 4,52 & 4,19 & $-0,33$ \\
\hline 3 & $\begin{array}{l}\text { Adanya penjadwalan yang baik } \\
\text { dan rutin kegiatan manasik haji di } \\
\text { daerah }\end{array}$ & 4,40 & 4,19 & $-0,21$ \\
\hline 4 & $\begin{array}{l}\text { Kejelasan penyampaian materi } \\
\text { dan jawaban terhadap pertanyaan } \\
\text { saat manasik haji }\end{array}$ & 4,32 & 3,98 & $-0,34$ \\
\hline 5 & $\begin{array}{l}\text { Kesigapan petugas dalam } \\
\text { menjawab dan menyelesaikan } \\
\text { permasalahan yang dialami } \\
\text { Jemaah }\end{array}$ & 4,43 & 3,84 & $-0,59$ \\
\hline 6 & $\begin{array}{l}\text { Pemberian kepastian informasi } \\
\text { jadwal keberangkatan calon } \\
\text { jemaah }\end{array}$ & 4,61 & 4,18 & $-0,43$ \\
\hline 7 & $\begin{array}{l}\text { Makanan yang sesuai selera } \\
\text { jemaah di asrama haji }\end{array}$ & 4,37 & 3,78 & $-0,59$ \\
\hline 8 & $\begin{array}{l}\text { Kesigapan petugas dalam } \\
\text { mengarahkan jemaah yang ingin } \\
\text { berangkat atau datang dari tanah } \\
\text { suci }\end{array}$ & 4,46 & 4,07 & $-0,39$ \\
\hline 9 & $\begin{array}{l}\text { Jemaah diberikan } \\
\text { bimbingan/penyuluhan pasca haji }\end{array}$ & 4,04 & 4,04 & 0,00 \\
\hline
\end{tabular}




\begin{tabular}{|c|c|c|c|c|}
\hline No & Daftar Pertanyaan & Importance & Performance & Gap \\
\hline 10 & $\begin{array}{l}\text { Ketepatan waktu bekerja } \\
\text { pegawai/petugas haji (disiplin) }\end{array}$ & 4,36 & 4,02 & $-0,33$ \\
\hline 11 & $\begin{array}{l}\text { Pegawai/petugas menguasai seluk } \\
\text { beluk haji dan isu mutakhir } \\
\text { keadaan di Arab Saudi }\end{array}$ & 4,52 & 3,86 & $-0,67$ \\
\hline 12 & $\begin{array}{l}\text { Petugas/pegawai yang ramah dan } \\
\text { murah senyum }\end{array}$ & 4,40 & 4,08 & $-0,32$ \\
\hline 13 & Petugas/pegawai yang bersahabat & 4,44 & 4,03 & $-0,41$ \\
\hline 14 & Petugas/pegawai berpakaian rapi & 4,18 & 4,12 & $-0,06$ \\
\hline 15 & $\begin{array}{l}\text { Petugas memberi perhatian tanpa } \\
\text { membedakan strata jemaah }\end{array}$ & 4,37 & 3,96 & $-0,41$ \\
\hline 16 & $\begin{array}{l}\text { Adanya pelayanan yang baik } \\
\text { dalam pemeriksaan kesehatan } \\
\text { jemaah sebelum pemberangkatan } \\
\text { (di daerah) }\end{array}$ & 4,50 & 4,10 & $-0,40$ \\
\hline 17 & $\begin{array}{l}\text { Pemberian pelayan kesehatan bagi } \\
\text { jemaah sakit }\end{array}$ & $4,5^{8}$ & 3,98 & $-0,60$ \\
\hline 18 & $\begin{array}{l}\text { Tersedia adanya tempat } \\
\text { pengaduan untuk barang } \\
\text { tercecer/hilang barang jemaah }\end{array}$ & 4,44 & 3,77 & $-0,68$ \\
\hline 19 & $\begin{array}{l}\text { Ketersediaan dan keterbukaan } \\
\text { Kemenag Kota Banjarmasin dalam } \\
\text { menerima setiap keluhan }\end{array}$ & 4,40 & 3,86 & $-0,54$ \\
\hline 20 & $\begin{array}{l}\text { Halaman kantor Kemenag Kota } \\
\text { Banjarmasin yang luas }\end{array}$ & 4,17 & 3,80 & $-0,37$ \\
\hline 21 & $\begin{array}{l}\text { Sarana praktek manasik haji yang } \\
\text { lengkap }\end{array}$ & 4,51 & 3,96 & $-0,56$ \\
\hline 22 & $\begin{array}{l}\text { Adanya sarana, prasarana, fasilitas } \\
\text { pendaftaran haji yang memadai }\end{array}$ & $4,3^{8}$ & 3,99 & $-0,39$ \\
\hline 23 & $\begin{array}{l}\text { Adanya perlengkapan atribut } \\
\text { jemaah yang baik (buku } \\
\text { bimbingan, koper, tas } \\
\text { jinjing/dokumen, seragam, gelang } \\
\text { identitas) }\end{array}$ & 4,63 & 4,26 & $-0,38$ \\
\hline 24 & $\begin{array}{l}\text { Tempat tidur yang nyaman saat di } \\
\text { asrama haji }\end{array}$ & 4,44 & 4,29 & $-0,16$ \\
\hline 25 & $\begin{array}{l}\text { Kamar mandi yang nyaman di } \\
\text { asrama haji }\end{array}$ & 4,52 & 4,22 & $-0,30$ \\
\hline 26 & $\begin{array}{l}\text { Kebersihan, kerapian dan } \\
\text { penataan ruang/fasilitas di } \\
\text { Kemenag Kota Banjarmasin }\end{array}$ & 4,37 & 3,94 & $-0,42$ \\
\hline 27 & $\begin{array}{l}\text { Transportasi yang mengantarkan } \\
\text { jemaah menuju asrama haji atau } \\
\text { embarkasi dan sebaliknya }\end{array}$ & 4,57 & 4,33 & $-0,23$ \\
\hline
\end{tabular}

Berdasarkan tabel diatas maka dapat diperoleh kesimpulan bahwa hanya ada satu atribut memiliki nilai nol yang tidak ada gap artinya sudah memenuhi harapan jemaah (puas) yaitu pada pertanyaan item (Qg) jemaah diberikan bimbingan/penyuluhan pasca haji sedangkan atribut lain memiliki nilai negatif 
tertinggi adalah pertanyaan item (Q18) tersedia adanya tempat pengaduan untuk barang tercecer/hilang milik jemaah.

Setelah memuat ranking maka tahap selanjutnya adalah melakukan Importance-Performance Analysis dengan memasukkan nilai mean pertanyaan dari setiap item pertanyaan berdasarkan variabel kepentingan (importance) dengan kinerja (performance) untuk membagi diagram digunakan sumbu $X$ dan $Y$ yang diperoleh dari hasil total seluruh item variabel pertanyaan kepentingan (importance) sebagai sumbu $Y$ dan total seluruh item variabel kinerja (performance) sebagai sumbu $X$. Hasil yang didapatkan adalah sebagai berikut.

Gambar 3. Pemetaan Importance Performance Analysis berdasarkan item

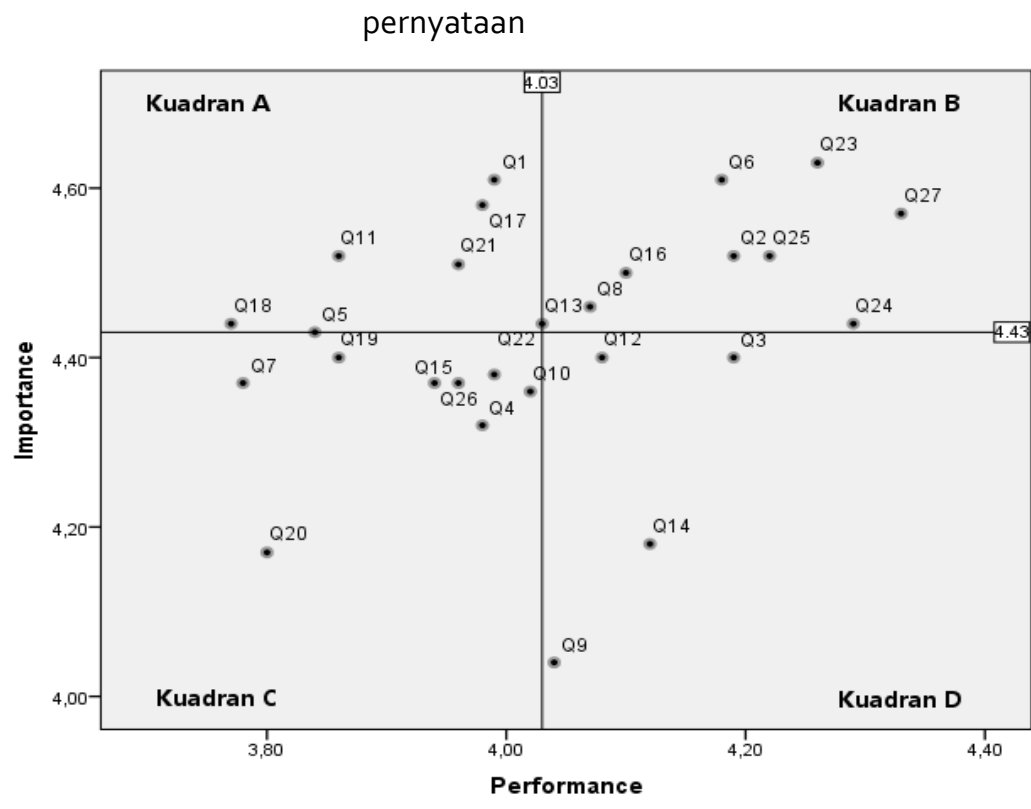

Berdasarkan dari diagram tersebut, maka diperoleh atribut-atribut yang masuk ke dalam beberapa kuadran. Berikut interpretasi masing-masing kuadran. Atribut-atribut pada kuadran A memiliki tingkat performance di bawah nilai performance rata-rata keseluruhan $(4,03)$ tetapi tingkat importance berada diatas nilai importance rata-rata keseluruhan $(4,43)$. Nilai importance yang tinggi mencerminkan bahwa jemaah mempunyai harapan yang tinggi pada atribut tersebut, tetapi Kemenag Kota Banjarmasin memiliki performance di bawah dari harapan jemaah. Akan sangat tidak baik konsekuensinya apabila Kemenag Kota Banjarmasin tidak memperhatikan hal yang dianggap penting oleh jemaah. Jika perbaikan pada atribut-atribut ini dilakukan maka akan menghasilkan peningkatan besar. Oleh karena itu, pihak Kemenag Kota Banjarmasin dianjurkan untuk memprioritaskan perbaikan pada atribut-atribut yang masuk dalam kuadran A, yaitu: (Q1) Pelayanan yang cepat dan tepat dalam memberikan informasi keberangkatan/pemanggilan jemaah $\left(\mathrm{Q}_{5}\right)$ Kesigapan petugas dalam 
menjawab dan menyelesaikan permasalahan yang dialami jemaah (Q17) Pemberian pelayan kesehatan bagi jemaah sakit (Q21) Sarana praktek manasik haji yang lengkap (Q11) Pegawai/petugas menguasai seluk beluk haji dan isu mutakhir keadaan di Arab Saudi (Q18) Tersedia adanya tempat pengaduan untuk barang tercecer/hilang barang Jemaah.

Atribut-atribut pada kuadran B memiliki tingkat kinerja dan kepentingan yang sama-sama tinggi performace dan importance dari atribut-atribut ini berada diatas tingkat performance dan importance rata-rata keseluruhan atribut. Atributatribut yang ada pada level ini merupakan kekuatan Kemenag Kota Banjarmasin. Kemenag Kota Banjarmasin sudah melakukan hal-hal yang baik untuk hal yang memang dianggap penting bagi jemaah haji. Atribut-atribut ini adalah kontributor utama dalam menciptakan kepuasan jemaah sehingga harus dipertahankan. Ada 9 atribut yang masuk dalam kuadran B yaitu (08) Kesigapan petugas dalam mengarahkan jemaah yang ingin berangkat atau datang dari tanah suci (Q16) Adanya pelayanan yang baik dalam pemeriksaan kesehatan jemaah sebelum pemberangkatan (di daerah) (Q2) Kemudahan dalam mengurus dokumendokumen pendaftaran dan pemberkasan calon jemaah haji (Q25) Kamar mandi yang nyaman di asrama haji (Q24) Tempat tidur yang nyaman saat di asrama haji (Q27) Adanya transportasi yang mengantarkan jemaah menuju asrama haji atau embarkasi dan sebaliknya (Q23) Adanya perlengkapan atribut jemaah yang baik (buku bimbingan, koper, tas jinjing/dokumen, seragam, gelang identitas) (06) Pemberian kepastian informasi jadwal keberangkatan calon jemaah (013) Petugas/pegawai yang bersahabat.

Atribut-atribut pada kuadran C memiliki tingkat performance yang samasama berada di bawah standar rata-rata atribut keseluruhan. Pada kuadran $C$ ini Kemenag Kota Banjarmasin dapat mengambil sikap selektif berdasarkan dari pergeseran tingkat kepentingan dari setiap atribut tersebut. Jika dimasa mendatang jemaah menganggap atribut tersebut tingkat kepentingannya meningkat, maka Kemenag Kota Banjarmasin dapat pula meningkatkan kinerjanya. Bisa juga tingkat kepentingan dari atribut ini ditingkatkan dengan proses edukasi. Ada 8 atribut yang masuk kuadran ini antara lain: (Q7) Makanan yang sesuai selera jemaah di asrama haji. (Q19) Ketersediaan dan keterbukaan Kemenag Kota Banjarmasin dalam menerima setiap keluhan. (Q15) Petugas memberi perhatian tanpa membedakan strata jemaah. (Q26) Kebersihan, kerapian dan penataan ruang/fasilitas di Kemenag Kota Banjarmasin. (Q22) Adanya sarana, prasarana, fasilitas pendaftaran haji yang memadai. (Q10) Ketepatan waktu bekerja pegawai/petugas haji (disiplin). (Q4) Kejelasan penyampaian materi dan jawaban terhadap pertanyaan saat manasik haji. (Q20) Halaman kantor Kemenag Kota Banjarmasin yang luas.

Atribut yang berada pada kuadran D adalah indikasi adanya investasi yang tidak efisien. Kemenag Kota Banjarmasin mempunyai performance yang baik untuk halhal yang tidak penting. Ada dua langkah yang dapat dilakukan Kemenag Kota 
Banjarmasin dengan hasil seperti ini. Pertama melakukan penurunan tingkat investasi untuk yang berhubungan dengan atribut ini. Pemikirannya sederhana, ternyata Kemenag Kota Banjarmasin melakukan hal yang baik tetapi tidak memberikan value yang dapat menciptakan kepuasan jemaah. Kedua tetap fokus mempertahankan performance untuk atribut ini dengan alasan bahwa tingkat kepentingan dari atribut ini akan meningkat dimasa mendatang. Justru Kemenag Kota Banjarmasin akan mendapat kelebihan (unggul) karena sudah mempunyai performance yang baik. Ada 4 atribut yang masuk kuadran ini antara lain (Q12)

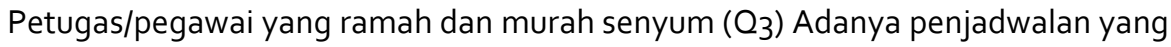
baik dan rutin kegiatan manasik haji di daerah (Qg) Jemaah diberikan bimbingan/penyuluhan pasca haji dan (Q14) Petugas/pegawai berpakaian rapi.

\section{Simpulan}

Berdasarkan hasil analisis kuadran kartesius maka dapat diambil kesimpulan bahwa variabel dimensi daya tanggap (responsiveness) dan jaminan (assurance) menjadi prioritas utama untuk dilakukan perbaikan, karena berada di kuadran A, adapun secara atribut yang juga menjadi prioritas utama untuk dilakukan perbaikan adalah tersedia adanya tempat pengaduan untuk barang tercecer/hilang barang jemaah, pegawai/petugas menguasai seluk beluk haji dan isu mutakhir keadaan di Arab Saudi, pelayanan yang cepat dan tepat dalam memberikan informasi keberangkatan/pemanggilan jemaah, pemberian pelayan kesehatan bagi jemaah sakit, serta sarana praktek manasik haji yang lengkap. 


\section{Referensi}

Gamble, M., \& Gambel, T. K. (2002). Communicaton Works. Boston: McGraw-Hill Collage. Gronroos, C. (2000). Service Management and Marketing: A Moment of Truth. Singapore: Maxwell Macmillan International.

Ivancevich, Lorensi, Skinner, \& Crosby. (2000). Manajemen Kualitas dan Kompetitif Terjemahan Muhammad Musa. Jakarta: Fajar Agung.

Kashmir. (2005). Etika Customer Service. Jakarta: Raja Grafindo Persada.

Khaliq, R. (2018a). Importance Performance Analysis Dalam Kasus Kepuasan Konsumen Usaha Laundry. Alhadharah: Jurnal Ilmu Dakwah, 17(34), 47.

Khaliq, R. (2018b). Pengaruh Funtional Quality, Technical Quality Terhadap Kepuasan Konsumen Dan Word Of Mouth Communication Konsumen Laundry ABC. AtTaradhi: Jurnal Studi Ekonomi, 9(2), 104-112.

Lupiyoadi, \& Rambat, H. (2006). Manajemen Pemasaran Jasa. Jakarta: Salemba Empat.

Mangkuto, J. M. (2008). Panduan Praktis Manasik Haji Sesuai Sunnah Rasulullah SAW. Jakarta: Amzah.

Martilla, J. A., \& James, J. C. (1977). Importance-performance analysis. The journal of marketing, 77-79.

Nahrawi, M. N., \& Syaukani, I. (2009). Manajemen pelayanan haji di Indonesia. Departemen Agama RI, Badan Litbang dan Diklat, Puslitbang Kehidupan Keagamaan.

Nidjam, A., \& Hanan, A. (2001). Manajemen Haji: Studi Kasus dan Telaah Implementasi Knowledge Workers. Zikrul Hakim.

Parasuraman, A., Zeithaml, V. A., \& Berry, L. L. (1985). A Conceptual Model of Service Quality and Its Implications for Future Research. the Journal of Marketing, 49(4), 41-50.

Sensuse, D. I., \& Maulana, M. (2011). Perancangan Strategis Sistem Informasi: Studi Kasus Direktorat Jenderal Penyelenggaraan Haji dan Umrah Departemen Agama RI. Jurnal Sistem Informasi, 7(1), 1-12.

Sumarwan, U. (2003). Perilaku Konsumen: Teori dan Penerapannya dalam Pemasaran. Jakarta: Ghalia Indonesia.

Sunyoto, D. (2012). Dasar-dasar manajemen pemasaran. Yogyakarta: Caps.

Taufiqurrahman. (2009). Manasik Haji \& Ziarah Spiritual. Malang: UIN-Malang Press.

Wijaya, T. (2011). Manajemen kualitas jasa. Jakarta: PT. Indeks.

Yuriansyah, A. L. (2013). Persepsi Tentang Kualitas Pelayanan, Nilai Produk Dan Fasilitas Terhadap Kepuasan Pelanggan. Management Analysis Journal, 2(1).

Zaenal Mukarom, Z., \& Muhibudin Wijaya Laksana, M. (2015). Manajemen Pelayanan Publik. Pustaka Setia. 